\title{
EFEKTIVITAS PENERAPAN E-KINERJA DALAM MENINGKATKAN KINERJA APARATUR SIPIL NEGARA PADA BADAN KEPEGAWAIAN DAERAH PROVINSI MALUKU
}

\author{
Oleh \\ Muflihun Waliulu' ${ }^{1}$, \\ Sampara Lukman $^{2}$, Kusworo ${ }^{3}$ \\ ${ }^{1)}$ Badan Kepegawaian Daerah Provinsi Maluku \\ Program Magister Terapan Studi Pemerintahan Daerah Institut Pemerintahan Dalam Negeri \\ abulexxxi20@gmail.com \\ ${ }^{2,3)}$ Institut Pemerintahan Dalam Negeri
}

\begin{abstract}
$T_{i}$ is study aims to determine and analyze the Effectiveness of the Application of E-Kinerja in Improving the Performance of State Civil Servants in the Regional Civil Service Agency of Maluku Province, then to find out the inhibiting factors in its application, as well as knowing what solutions are given in overcoming these inhibiting factors, in order to improve the performance of the apparatus. The research design used in this research is a descriptive research design with a qualitative approach, with the use of primary data and secondary data obtained through the process of interviews, observation and documentation from data sources in the form of person, place, and paper.

The results of this study indicate that the effectiveness of the application of E-Kinerja in improving the performance of state civil servants at the Maluku Provincial Civil Service Agency has not been effective. This is in accordance with the theory used, namely the theory of effectiveness according to Makmur, some inhibiting factors were found, namely adaptability, there are no specific rules governing it, and lack of facilities and infrastructure. Therefore, to overcome the inhibiting factors for the application of E-performance which aims to improve the performance of the apparatus, several solutions are implemented, namely the appointment of an E-performance admin, specific rules regarding E-performance, and renewal of E-performance based on android and IOS so that the process of implementing E-performance can run effectively.
\end{abstract}

Keywords: effectiveness, the application of e-performance, apparatus performance.

\section{ABSTRAK}

$\mathrm{P}$ enelitian ini bertujuan untuk mengetahui dan menganalisis Efektivitas Penerapan E-Kinerja Dalam Meningkatkan Kinerja Aparatur Sipil Negara Pada Badan Kepegawaian Daerah Provinsi Maluku, kemudian untuk mengetahui faktor penghambat dalam penerapannya, serta mengetahui solusi apa yang diberikan dalam mengatasi faktor penghambat tersebut, dalam rangka meningkatkan kinerja aparatur. Desain penelitian yang digunakan dalam penelitian ini adalah desain penelitian deskriptif dengan pendekatan kualitatif, dengan penggunaan data primer dan data sekunder yang diperoleh melalui proses wawancara, observasi dan dokumentasi dari sumber data berupa person, place,dan paper. 
Hasil penelitian ini menunjukkan bahwa Efektivitas Penerapan E-Kinerja Dalam Meningkatkan Kinerja Aparatur Sipil Negara Pada Badan Kepegawaian Daerah Provinsi Maluku belum efektif. Hal ini sesuai dengan teori yang digunakan, yaitu teori efektivitas menurut Makmur, masih ada beberapa faktor penghambat yang ditemukan, yaitu kemampuan adaptasi, belum adanya aturan khusus yang mengatur, dan kurangnya saran dan prasarana. Oleh karena itu, untuk mengatasi faktor penghambat penerapan E-kinerja yang bertujuan untuk meningkatkan kinerja aparatur beberapa solusi yang dilaksanakan, yaitu penunjukan admin E-kinerja, aturan khusus terkait E-kinerja, dan pembaharuan E-kinerja berbasis android dan IOS sehingga proses penerapan E-kinerja dapat berjalan efektif.

Kata kunci: efektivitas, penerapan e-kinerja, kinerja aparatur

\section{PENDAHULUAN}

Kesemrawutan yang terjadi di dalam dunia pemerintahan baik di pusat maupun di daerah terutama terhadap kinerja Aparatur yang bekerja seenaknya dan tidak akuntabel. Hal ini menyebabkan carut-marut terhadap pekerjaan aparatur maupun instansi tersebut.

Bisa kita lihat dari berbagai berita baik media cetak maupun media elektronik di mana banyak aparatur yang mangkir pada jam kerja dan berada pada tempat umum seperti cafe, rumah kopi ataupun mall untuk memenuhi kepentingan pribadi dalam menggunakan waktu kerja dan menyampingkan kepentingan orang banyak baik pada level atas sampai kepada level paling bawah. Salah satu contoh yang terjadi pada pemerintah provinsi Maluku ialah pemberitaan Sekretaris Daerah Maluku dan sejumlah pimpinan Organisasi Perangkat Daerah nongkrong pada saat jam kerja pukul 10.00-12.00 WIB pada sebuah rumah kopi menggunakan pakaian dinas harian (https://terasmaluku.com/sekda-malukunongkrong-bersama-pimpinan-skpd-dirumah-kopi-saat-jam-kerja/, diakses pada 11 desember 2019).

Penilaian kinerja aparatur telah dilakukan oleh pemerintah baik pusat maupun daerah sejak dulu melalui Daftar Penilaian Pelaksanaan Pekerjaan Pegawai Negeri Sipil atau yang biasa disingkat menjadi DP3 PNS dan diatur dalam
Peraturan Pemerintah Nomor 10 Tahun 1979. Kenyataannya, DP3 PNS memiliki kekurangan dalam hal penilaiannya terkesan tertutup yang sering dipertanyakan objetivitasnya, karena penilaian yang dilakukan atasan bersifat rahasia dan mutlak dalam menilai kinerja seseorang tanpa menggunakan indikator yang jelas.

Melihat berbagai kekurangan yang ada pada DP3 PNS maka pemerintah membuat formula baru dalam menilai kinerja pegawai, yaitu dengan merubah DP3 PNS menjadi Sasaran Kerja Pegawai (SKP) yang diatur dalam Peraturan Pemerintah Nomor 46 tahun 2011 sebagai rencana kerja dan target yang akan dicapai pegawai. Penilaian Prestasi Kerja dilakukan berdasarkan prinsip objektif, terukur, akuntabel, partisipatif dan transparan. Dalam Peraturan Pemerintah Nomor 46 tahun 2011 tentang Penilaian Prestasi Kerja Pegawai Negeri Sipil Pasal 1 ayat 2 menyatakan bahwa Penilaian prestasi kerja PNS adalah suatu proses penilaian secara sistematis yang dilakukan oleh pejabat penilai terhadap sasaran kerja pegawai dan perilaku kerja PNS.

Upaya peningkatan kinerja aparatur sipil negara di Provinsi Maluku telah dilakukan oleh Badan Kepegawaian Daerah Provinsi Maluku sebagai Organisasi yang memiliki fungsi penunjang kepegawaian, di mana fungsi penunjang kepegawaian ini bersifat kompleks dari pengadaan dan informasi kepegawaian, mutasi dan promosi, juga terkait penegakan disiplin, penilaian kinerja dan penghargaan kepada 
aparatur dalam lingkup pemerintah Provinsi Maluku.

Penerapan penilaian kinerja melalui system elektronik kinerja (E-kinerja) pada tahun 2018 di mana setiap aparatur diwajibkan membuat sasaran kerja pegawai sebagai rencana kerja pegawai dalam kurun waktu satu tahun anggaran. Melalui E-kinerja atasan langsung dapat memantau dan mengawasi apa saja yang dikerjakan oleh seorang aparatur sehingga penilaian yang diberikan sesuai dengan kinerja aparatur tersebut.

Selain untuk membuat laporan kinerja hari harian, E-kinerja juga berfungsi untuk mengawasi dan menilai kinerja Aparatur yang ada dalam lingkup Badan Kepegawaian Daerah maupun organisasi perangkat Daerah lainnya. E-kinerja merupakan aplikasi yang berbasis pada website yang digunakan oleh Pemerintah Provinsi Maluku untuk melakukan perhitungan prestasi kerja dan pemberian insentif kerja dalam hal ini berupa Tunjangan Kinerja Daerah.

Penilaian kinerja pegawai melalui E-kinerja berdasarkan Peraturan Gubernur Nomor 1.a tahun 2017 tentang Tunjangan Kinerja Daerah Provinsi Maluku. Di mana item penilaiannya adalah disiplin, tanggung jawab, kerja sama, inovasi dan produktivitas. Pedoman pembuatan dan penetapan Peraturan Gubernur Nomor 1.a tahun 2017 tentang Tunjangan Kinerja Daerah Provinsi Maluku ialah Peraturan Pemerintah Nomor 46 tentang Penilaian Prestasi Kerja Pegawai Negeri Sipil di mana Peraturan Pemerintah ini tidak relevan untuk digunakan sebagai patokan penilaian kinerja pegawai, sebab peraturan pemerintah ini bertujuan untuk menilai prestasi kerja pegawai negeri sipil selama per semester atau per tahun.

Berdasarkan Peraturan Gubernur Nomor 1.a tahun 2017 tentang Tunjangan Kinerja Daerah Provinsi Maluku maka system penilaian yang diberikan kepada kinerja aparatur sering dipertanyakan dan membatasi nilai yang akan diperoleh oleh aparatur, dengan kata lain penilaian yang dilakukan belum dapat dikatakan sesuai dengan apa yang diharapkan oleh para aparatur yang telah menjalankan kinerjanya. Contohnya pada item penilaian disiplin, bobot nilai disiplin merupakan bobot nilai yang lebih besar, yaitu 30\% dibandingkan item penilaian lainnya, di mana pada lampiran Peraturan Gubernur Maluku Nomor 1.a tahun 2017 menyebutkan bahwa seorang aparatur bisa mendapatkan nilai 100 jika setiap hari kerja hadir dan 10 kali hadir mengikuti kegiatan kenegaraan, hal ini tentu saja mustahil karena pada bulan berjalan tidak kita temukan kegiatan kenegaraan sampai 10 kegiatan.

Hal itu dapat menimbulkan berbagai bias terhadap tujuan awal dari pada system elektronik kinerja, yaitu untuk memperbaiki dan meningkatkan kinerja aparatur yang berada pada lingkup pemerintah Provinsi Maluku umumnya dan pada Badan kepegawaian Daerah khususnya. Di mana system elektronik kinerja memiliki fungsi pengawasan haruslah didukung oleh stimulan lainnya, yaitu reward atau kompensasi sebagai bentuk penghargaan terhadap kinerja yang diberikan kepada para aparatur sehingga dapat meningkatkan kinerja para aparatur tersebut.

\section{KAJIAN PUSTAKA}

\section{Pemerintahan Daerah}

Dalam Undang-Undang Nomor 23 Tahun 2014 tentang Pemerintahan daerah Pasal 1 ayat 2 dijelaskan bahwa: Pemerintahan Daerah adalah penyelenggaraan urusan pemerintahan oleh pemerintah daerah dan dewan perwakilan rakyat daerah menurut asas otonomi dan tugas pembantuan dengan prinsip otonomi seluas-luasnya dalam sistem dan prinsip Negara Kesatuan Republik Indonesia sebagaimana dimaksud dalam Undang-Undang Dasar Negara Republik Indonesia Tahun 1945. 


\section{Efektivitas}

Menurut Barnard efektivitas dalam mamik dan syarif (2016:7), efektivitas berkaitan dengan pencapaian tujuan. Menurut Rusdiana dan Gazhin (2014:80), bahwa efektivitas mengacu pada pencapaian target secara kuantitas dan kualitas. Semakin besar persentase target suatu program yang tercapai maka semakin tinggi tingkat efektivitasnya. Efektivitas merupakan refleksi kemampuan untuk memengaruhi terjadinya suatu produk. Efektivitas menunjukkan besarnya pengaruh dalam proses produksi.

Makmur (2013:7) menjelaskan bahwa apabila dilihat dari segi kriteria efektivitas, unsur-unsurnya antara lain adalah sebagai berikut.

1. Ketetapan penentuan waktu;

2. Ketetapan perhitungan biaya;

3. Ketetapan dalam pengukuran;

4. Ketetapan dalam menentukan pilihan;

5. Ketetapan berpikir;

6. Ketetapan dalam melakukan perintah;

7. Ketetapan dalam menentukan tujuan; dan

8. Ketetapan-ketetapan sasaran.

\section{E-kinerja}

Menurut Putri dkk, (2014) elektronik kinerja atau e-kinerja adalah salah satu aplikasi berbasis web untuk menganalisis kebutuhan jabatan, beban kerja jabatan dan beban kerja unit/satuan kerja organisasi sebagai dasar perhitungan prestasi kerja dan pemberian insentif kerja. Tujuan e-kinerja adalah untuk peningkatan kinerja PNS dan organisasi, Melakukan penataan dan penyempurnaan organisasi, Melakukan penilaian atas prestasi kerja PNS dan organisasi, Memberikan rasa keadilan dan meningkatkan kesejahteraan PNS, Mendorong terciptanya kompetisi kerja yang sehat di antara PNS, Meningkatkan kompetensi SDM dan jabatan yang dimiliki PNS, dan Menumbuhkan kreativitas dan inovasi kerja PNS

\section{Penilaian Kinerja}

Menurut Rahadi (2010:120), Penilaian kinerja Pegawai Negeri Sipil, adalah penilaian secara periodik pelaksanaan pekerjaan seorang Pegawai Negeri Sipil. Tujuan penilaian kinerja adalah untuk mengetahui keberhasilan atau ketidakberhasilan seorang Pegawai Negeri Sipil, dan untuk mengetahui kekurangan-kekurangan dan kelebihan-kelebihan yang dimiliki oleh Pegawai Negeri Sipil yang bersangkutan dalam melaksanakan tugasnya. Hasil penilaian kinerja digunakan sebagai bahan pertimbangan dalam pembinaan Pegawai Negeri Sipil, antara lain pengangkatan, kenaikan pangkat, pengangkatan dalam jabatan, pendidikan dan pelatihan, serta pemberian penghargaan.

\section{METODE PENILITIAN}

Penelitian ini menggunakan metode penelitian kualitatif dengan pendekatan deskriptif. Pengumpulan data dilakukan dengan menggunakan observasi, wawancara dan dokumentasi. Analisis data, yaitu mereduksi data, penyajian data dan penarikan simpulan. Penelitian ini bertujuan untuk mengetahui dan menggambarkan serta menganalisis bagaimana efektivitas E-kinerja dalam meningkatkan kinerja ASN pada Badan Kepegawaian Daerah Provinsi Maluku.

\section{HASIL PENELITIAN}

Efektivitas memiliki persepsi yang bersumber dari ilmu administrasi yang berkembang seiring berjalannya waktu ke dalam berbagai kehidupan manusia sebagai proses pencapaian tujuan yang di inginkan. Penerapan E-kinerja sebagai pertanggungjawaban terhadap pemberian insentif (tukir) dan sebagai 
bentuk penilaian capaian sasaran Kinerja Pegawai yang dilakukan setiap tahunnya dengan item penilaian antara lain disiplin, tanggung jawab, inovasi, kepemimpinan dan produktivitas dengan bobot nilai yang berbeda pada itemnya.

\section{Ketepatan Penentuan Waktu}

Ketepatan waktu penginputan dan penilaian kinerja sudah diatur untuk meminimalkan keluhan dan mengoptimalkan kinerja aparatur untuk melaksanakan tugas sesuai dengan sasaran kinerja pegawai yang telah dibuat oleh masing-masing aparatur, sehinggajikapara aparatur tidakbersungguhsungguh maka akan memengaruhi nilai yang didapatkan dan berdampak kepada tunjangan kinerja yang akan diberikan sesuai dengan nilai kinerja yang diberikan oleh atasannya. Setiap keputusan memiliki kelebihan dan kekurangan, perpanjangan waktu penginputan dan penilaian memiliki kelebihan, yaitu membantu para aparatur dengan berbagai keluhan yang telah disebutkan di atas untuk tetap bisa menginput kinerja dengan diberikan waktu tambahan, namun kekurangan yang dimiliki ialah dengan diperpanjangnya waktu penginputan, otomatis waktu verifikasi penilaian kinerja dan pemberian tunjangan kinerja menjadi mundur. Berdasarkan hasil pengamatan penulis pada Badan Kepegawaian Daerah sebagai lokus penelitian bahwa tidak ada keterlambatan penginputan maupun penilaian dari bulan april 2018 sampai bulan desember 2019.

\section{Ketepatan Perhitungan Biaya.}

Penentuan ketepatan perhitungan biaya melalui lima item penilaian kinerja tidak semua item penilaian sesuai peraturan yang berlaku berjalan sesuai dengan harapan dan tujuan yang ingin dicapai. Hal ini disebabkan oleh ada beberapa item penilaian yang belum berjalan secara keseluruhan dan belum bersifat objektif sesuai penilaian kinerja yang di tetapkan. Perhitungan penilaian kinerja
ASN di Badan Kepegawaian Daerah Provinsi Maluku dihitung berdasarkan lima item penilaian kinerja dengan masing-masing item memiliki bobot yang berbeda-beda yang kemudian menjadi tolak ukur untuk menentukan besaran tunjangan kinerja yang akan diperoleh oleh para ASN. Ketepatan perhitungan pembiayaan Tunjangan Kinerja Daerah pada Badan Kepegawaian Daerah Provinsi Maluku belum efektif yang disebabkan oleh item penilaian kinerja yang secara keseluruhan belum terukur dengan baik. Hal ini memengaruhi penilaian kinerja yang dilakukan masih bersifat subjektif.

\section{Ketepatan dalam Pengukuran}

Ketepatan pengukuran item penilaian kinerja melalui E-kinerja belum berjalan efektif sesuai dengan aturan yang berlaku yang mana kelima item penilaian kinerja (Disiplin, tanggung jawab, kerja sama, inovasi dan Produktivitas) ini dirasakan tidak relevan dengan tujuan dan manfaat yang diinginkan dalam penerapan E-kinerja ini. Kelima item penilaian ini merupakan hasil copy paste dari PP no.46 tahun 2011 yang bertujuan untuk menilai SKP yang memiliki jangka waktu penilaian minimal per semester atau per tahun anggaran dan tidak relevan untuk menilai kinerja ASN dalam bulan berjalan untuk dijadikan sebagai dasar pemberian tunjangan, sehingga kriteria ketepatan dalam pengukuran tidak berjalan efektif.

\section{Ketepatan dalam Menentukan Pilihan}

Ketepatan dalam menentukan pilihan, yaitu ketepatan penerapan E-kinerja guna meningkatkan kinerja aparatur dalam pelaksanaannya belum bisa dikatakan sebagai pilihan yang tepat sesuai tujuan yang ingin dicapai. Hal ini disebabkan belum adanya aturan khusus yang mengatur terkait penerapan E-kinerja sehingga memengaruhi iklim persaingan kerja yang sesuai dengan apa yang menjadi tujuan awal penerapan E-kinerja untuk meningkatkan 
kinerja aparatur. Berdasarkan pengamatan di lokasi penelitian, penulis juga dapat menggambarkan bahwa penerapan E-kinerja memang bertujuan untuk meningkatkan kinerja ASN yang selama ini bekerja tanpa ada pengawasan sehingga banyak pelanggaran disiplin yang terjadi. Dengan diterapkannya E-kinerja para ASN lebih serius untuk memenuhi target SKP yang telah dibuat namun hal ini terbentur dengan aturan yang bisa dikatakan prematur sehingga menjadikan target yang ingin dicapai berjalan merangkak atau belum efektif sebagai pilihan yang tepat dalam mencapai tujuan awal penerapan E-kinerja.

\section{Ketepatan Berpikir}

ketepatan berpikir dalam hal ini ketepatan penerapan E-kinerja yang tujuan utamanya meningkatkan kinerja aparatur di lingkungan Pemerintah Provinsi Maluku khususnya Badan Kepegawaian Daerah belum berjalan efektif sesuai dengan apa yang ingin dicapai. Efek positif yang diberikan dirasakan belum maksimal meskipun Pemerintah Provinsi Maluku telah berupaya untuk meningkatkan kinerja aparaturnya berdasarkan pengawasan melalui E-kinerja. Hal ini dapat dilihat pada perbandingan tingkat kehadiran aparatur di Badan Kepegawaian Daerah Provinsi Maluku setelah diterapkan E-kinerja pada bulan april 2018 sebesar $84,2 \%$ dan tingkat ketidakhadiran sebesar 7,6\%, sedangkan tingkat kehadiran pada bulan April 2019 sebesar $84,4 \%$ dan tingkat ketidakhadiran sebesar 8,5\%. Hal ini membuktikan bahwa setelah adanya diterapkannya E-kinerja memengaruhi tingkat kehadiran aparatur walaupun perubahan yang terjadi tidak terlalu signifikan, hal ini dibuktikan dengan adanya aparatur yang masih melakukan pelanggaran disiplin yang terjadi pada lingkungan Badan Kepegawaian dalam mengemban tanggung jawabnya sebagai seorang aparatur terhadap jam kerja yang telah diatur di mana hal ini juga memengaruhi kinerjanya sebagai aparatur.

\section{Ketepatan Melakukan Perintah}

ketepatan dalam melakukan perintah, yaitu ketepatan perintah daripada pimpinan sampai kepada bawahan sudah tepat dan sesuai dengan peraturan yang telah berlaku. Hal ini disebabkan telah ditertibkannya SKP pada seluruh jajaran sejak diterapkannya E-kinerja yang menuntut setiap aparatur memiliki SKP yang merupakan turunan sasaran kinerja dari level yang paling tinggi sampai kepada level paling bawah sehingga terjalin kerja sama dan keseimbangan dalam mendukung dan menyelesaikan tugas masing-masing. Dengan diterapkannya e-kinerja maka para aparatur kini telah bekerja sesuai dengan koridor dalam hal ini sesuai dengan sasaran kinerja pegawai sebagai kontrak kerja bersifat hierarkis yang dijabarkan dari visi misi OPD kemudian turun kepada sasaran kinerja kepala OPD sampai kepada jajaran jabatan fungsional. Sehingga aparatur menjadi produktif untuk memenuhi target capaian yang telah dibuat. Hal ini merupakan langkah untuk memperbaiki iklim kerja yang selama ini tidak sehat.

\section{Ketepatan dalam Menentukan Tujuan}

Tujuan penerapan E-kinerja belum efektif karena masih ada hambatan yang perlu dibenahi sesuai dengan kebutuhan yang diperlukan dalam mencapai tujuan diterapkannya E-kinerja, di antaranya seperti item atau indikator penilaian yang kurang relevan dan membatasi hasil yang bisa diperoleh para aparatur yang membuat tujuan diterapkannya E-kinerja menjadi tidak maksimal seperti yang diharapkan. Sebelum diterapkannya e-kinerja Pemerintah Provinsi Maluku telah melakukan formulasi untuk meningkatkan kinerja aparatur melalui pemberian reward atau tunjangan kinerja daerah, namun hal ini tidak efektif dalam meningkatkan kinerja aparatur 
karena reward yang diberikan tanpa ada pertanggungjawaban terkait kinerja para aparatur. Kemudian dipilih e-kinerja sebagai bentuk pengawasan yang bertujuan untuk meningkatkan kinerja aparatur, namun terjadi permasalahan baru yang menjadikan kedua formula ini bertolak belakang, yaitu peraturan yang dirasa kurang rasional sehingga tujuan yang ingin dicapai menjadi terhambat atau berjalan lamban.

\section{Ketepatan Sasaran}

ketepatan-ketepatan sasaran dalam penerapan E-kinerja sudah berjalan namun belum sesuai dengan apa yang diharapkan. Hal ini dikarenakan belum adanya aturan khusus yang mengatur terkait penilaian yang sesuai dengan sasaran yang tepat antara target dan capaian kinerja yang relevan, juga belum terjadi sinkronisasi antara E-kinerja dengan tunjangan kinerja yang keduanya merupakan stimulan yang bertujuan untuk meningkatkan kinerja aparatur, sehingga disiplin aparatur menjadi menurun dan hal ini memengaruhi kinerja para aparatur tersebut.

\section{Faktor Penghambat Penerapan E-kinerja}

Berdasarkan hasil penelitian dan pengamatan yang penulis lakukan dan peroleh dari wawancara informan dan observasi pada lokasi penelitian, dapat dilihat beberapa faktor penghambat penerapan E-kinerja pada Badan Kepegawaian Daerah Provinsi Maluku sebagai berikut.

1. Kemampuan Adaptasi dari laporan kinerja manual kepada laporan kinerja berbasis elektronik.

Faktor adaptasi penerapan E-kinerja yang secara keseluruhan belum berjalan sesuai dengan harapan, hal ini dikarenakan tidak semua aparatur mampu menguasai teknologi informasi dan komunikasi (TIK) atau gagap terhadap teknologi, sehingga masih dibutuhkan pendampingan dan pengawasan dalam pengoperasian akun E-kinerja pada aparatur yang termasuk dalam kategori gaptek.

2. Belum adanya aturan khusus yang mengatur terkait penerapan E-kinerja dengan tunjangan kinerja.

Penggunaan aturan Tunjangan Kinerja terhadap penerapan E-kinerja tidak sesuai karena sangat berbeda penilaian laporan kinerja secara manual dengan online pada sisi transparansinya sehingga hal ini sangat berpengaruh terhadap kinerja pegawai yang merasa kurang puas dengan kelima indikator penilaian yang ada pada Peraturan Gubernur terkait tunjangan kinerja, sehingga dibutuhkannya aturan khusus terkait E-kinerja atau aturan yang bisa menyinkronkan antara E-kinerja dengan tunjangan kinerja tersebut.

3. Terbatasnya sarana dan prasarana yang ada pada lingkup Badan Kepegawaian Daerah Provinsi Maluku.

Faktor penghambat penerapan E-kinerja salah satunya, yaitu keterbatasan sarana dan prasarana sehingga dapat menimbulkan keterlambatan dan pengawasan yang kurang objektif, hal ini bisa berujung kepada laporan kinerja fiktif yang dilakukan oleh oknum aparatur yang tidak bertanggung jawab karena laporan kinerja yang diinput tidak secara berkala setiap hari kerja.

\section{Solusi untuk Mengatasi Faktor Penghambat Penerapan System Elektronik}

Setiap pilihan yang diambil untuk mencapai suatu tujuan, pasti memiliki faktor penghambat, baik yang sudah diprediksi ataupun yang belum diprediksi. Hal ini tentu memengaruhi pelaksanaan daripada pilihan yang telah ditentukan sehingga tujuan yang akan dicapai menjadi terhambat. Untuk 
menghadapi faktor penghambat yang ada maka diperlukan solusi sebagai jalan tengah untuk mengatasi hambatan tersebut.

1. Kemampuan Adaptasi dari laporan kinerja manual kepada laporan kinerja berbasis elektronik.

Penunjukan admin E-kinerja bertujuan untuk mengatasi masalah terkait proses adaptasi dari laporan kinerja manual kepada laporan kinerja berbasis elektronik, namun hal ini tidaklah bersifat berkelanjutan namun hanya sementara. Admin E-kinerja diberikan tanggung jawab untuk mendampingi dan melatih para aparatur yang gaptek guna menghindari kesalahan-kesalahan fatal yang diharapkan ke depannya mereka bisa mandiri dalam mengoperasikan akun e-kinerja masing-masing.

2. Belum adanya aturan khusus yang mengatur terkait penerapan E-kinerja dengan tunjangan kinerja.

Sebagai bentuk perbaikan terhadap aturan yang selama ini keliru dan menjadi penghambat untuk meningkatkan kinerja aparatur maka Badan Kepegawaian daerah telah melakukan audience dan mendapat persetujuan Gubernur di mana pada penyusunan Pergub No.1a Tahun 2017 tentang tunjangan kinerja daerah, Badan Kepegawaian Daerah tidak dilibatkan sehingga hal tersebut berujung kepada salah tafsir terkait PP No. 46 Tahun 2011 sehingga hal tersebut menjadi penghambatkepada peningkatan Kinerja aparatur. Dengan persetujuan Gubernur diharapkan Badan Kepegawaian Daerah Provinsi Maluku dapat menjadi pelopor untuk memperbaiki peraturan yang ada sebagai fungsi penunjang kepegawaian, di mana fungsi penunjang kepegawaian ini bersifat kompleks dari pengadaan dan informasi kepegawaian, mutasi dan promosi, juga terkait penegakan disiplin, penilaian kinerja dan penghargaan kepada aparatur dalam lingkup pemerintah Provinsi Maluku.

3. Terbatasnya sarana dan prasarana yang ada pada lingkup Badan Kepegawaian Daerah Provinsi Maluku.

Sebagai bentuk inovasi dengan keterbatasan dana, E-kinerja yang merupakan aplikasi bawaan dari aplikasi SIMPEG online Pemerintah Provinsi Maluku, maka langkah yang diambil dalam menanggulangi faktor penghambat terbatasnya sarana dan prasarana, yaitu dengan pengembangan system E-kinerja berbasis android dan IOS. Sehingga tidak membutuhkan pengadaan sarana dan prasarana yang banyak memakan biaya operasional, hal ini juga mempermudah para aparatur yang tidak dapat mengoperasikan akun e-kinerjanya pada komputer, namun bisa mengoperasikan smartphone.

\section{SIMPULAN}

1. Penerapan E-Kinerja Dalam Meningkatkan Kinerja Aparatur Sipil Negara Pada Badan Kepegawaian Daerah Provinsi Maluku belum efektif. Dalam penerapannya masih terdapat kekurangan dan hambatan sehingga belum bisa mencapai tujuan perubahan, yaitu meningkatkan kinerja aparatur pada Badan Kepegawaian Daerah Provinsi Maluku. Penekanan kekurangan atau permasalahan yang sangat berarti, yaitu belum adanya aturan khusus terkait dengan penerapan E-kinerja yang saat ini masih menggunakan aturan terkait tunjangan kinerja sehingga menimbulkan ketidakpuasan dari para aparatur terkait dengan item atau indikator yang tidak sesuai dan relevan.

2. Faktor penghambat penerapan E-kinerja dalam meningkatkan kinerja Aparatur Sipil Negara pada Badan Kepegawaian Daerah Provinsi Maluku adalah sebagai berikut. 
a. Kemampuan adaptasi dari laporan kinerja manual kepada laporan kinerja berbasis elektronik.

b. Belum adanya aturan khusus yang mengatur terkait penerapan E-kinerja dengan tunjangan kinerja.

c. Terbatasnya sarana dan prasarana yang ada pada lingkup Badan Kepegawaian Daerah Provinsi Maluku.

3. Solusi untuk mengatasi faktor penghambat penerapan system elektronik kinerja dalam meningkatkan kinerja Aparatur Sipil Negara pada Badan Kepegawaian Daerah Provinsi Maluku.

a. Solusi yang dilakukan terhadap lambannya adaptasi bagi para aparaturyang gagap teknologi dalam penerapan E-kinerja, yaitu dengan menunjuk admin E-kinerja di bawah Sub Bagian Kepegawaian untuk memberikan pelayanan bantuan penginputan laporan kinerja harian bagi mereka yang tidak dapat mengoperasikan komputer, juga perlahan-lahan dilatih untuk dapat mengoperasikan akun E-kinerja masing-masing aparatur yang belum bisa mengoperasikan komputer maupun akun E-kinerjanya sendiri

b. Bidang Pengadaan dan Informasi Kepegawaian bersama kepala Badan Kepegawaian Daerah sudah melakukan rapat dengan Gubernur Maluku pada bulan Februari terkait dengan pergub khusus E-kinerja dan beliau menyetujui terkait dengan usulan kami untuk menyinkronkan antara Pergub tunjangan kinerja dengan E-kinerja yang kami harapkan dengan sinkronnya kedua stimulan ini maka kinerja aparatur meningkat sesuai yang diharapkan, namun kami masih agak terlambat karena wabah pandemic ini sehingga kami masih berproses pada penyusunan draft bersama biro hukum.

c. Sarana dan prasarana yang ada pada Badan Kepegawaian Daerah Provinsi Maluku masih terbatas, tahap awal penerapan E-kinerja yang kami rancang tampilannya masih bersifat website sehingga hanya bisa diakses melalui komputer, bisa juga diakses melalui smartphone namun tampilan yang ditampilkan tidak sempurna. Untuk mengatasi masalah ini, kami sementara melakukan pembangunan E-kinerja berbasis android dan IOS yang ke depannya bisa diakses melalui smartphone masing-masing aparatur..

\section{SARAN}

Berdasarkan hasil penelitian yang telah peneliti lakukan dan analisis yang peneliti kemukakan berdasar fakta dan data di lapangan, oleh karena itu untuk menciptakan Efektivitas Penerapan E-Kinerja dalam Meningkatkan Kinerja ASN pada Badan Kepegawaian Daerah Provinsi Maluku, saran yang dapat diberikan ialah sebagai berikut.

1. Diharapkan kepada Pemerintah Provinsi Maluku dalam pengambilan keputusan atau kebijakan harusnya melibatkan Organisasi Perangkat Daerah terkait sehingga apa yang menjadi ketetapan di kemudian hari tidak hanya menguntungkan salah satu atau beberapa OPD saja dan tidak salah sasaran maupun melenceng daripada tujuan utama ditetapkannya keputusan tersebut.

2. Indikator penilaian yang digunakan pada Peraturan Gubernur Nomor 1.a Tahun 2017 tentang Tunjangan Kinerja sebaiknya ditinjau dan diperbaiki kembali karena tidak sesuai dengan kondisi yang ada dan terkesan 
terjadi pembatasan nilai yang akan diperoleh oleh para aparatur yang telah bekerja maksimal sehingga motivasi kinerja aparatur tersebut kembali menurun atau biasa saja.

3. Selanjutnya, diharapkan sinkronisasi antara kebijakan pemberian tunjangan kinerja dengan penerapan E-kinerja yang di mana keduanya merupakan formula untuk meningkatkan kinerja aparatur, yang mana tidak terjadi benturan antara kedua formula ini yang kemudian akan menjadi penghambat untuk meningkatkan kinerja para aparatur. Berbagai faktor penghambat dalam penerapan E-kinerja agar menjadi perhatian untuk diperbaiki dan menjadi pelajaran di kemudian hari dalam membuat kebijakan yang lain.

\section{DAFTAR PUSTAKA}

Mamik dan Usman Syarif. 2016. Manajemen Sumber Daya Manusia. Sidoarjo. Zifatama Publisher

Rusdiana dan Ghazin, Ahmad. 2014. AsasAsas Manajemen Berwawasan Global. Bandung. Pustaka Setia
Makmur. 2013.Efektivitas Kebijakan Kelembagaan Pengawasan. Bandung: Refika Aditama.

Rahadi, Dedi Rianto.2010. Manajemen Kinerja Sumber Daya Manusia. Malang. Tunggal Mandiri

\section{Peraturan Perundang-Undangan}

Undang-Undang Dasar Tahun 1945

Undang-Undang Nomor 23 Tahun 2014 tentang Pemerintahan daerah

Peraturan Pemerintah Nomor 46 Tahun 2011 tentang Penilaian Kinerja Pegawai Negeri Sipil

Peraturan Gubernur Nomor 1.a tahun 2017 tentang Tunjangan Kinerja Daerah Provinsi Maluku

\section{Sumber Lain}

Komara Eka Putri dkk.2014. Pengaruh Penerapan E-Kinerja dan Penghargaan (Reward) terhadap Kinerja Aparatur pengelola Keuangan di Lingkungan Pemerintahan Kota Banda aceh. Jurnal akuntansi. $3(4): 1-10$

https://terasmaluku.com/sekda-malukunongkrong-bersama-pimpinan-skpddi-rumah-kopi-saat-jam-kerja/, diakses pada 11 desember 2019 